\title{
Pengaturan Batas Usia Perkawinan Perspektif Keluarga Sakinah Muhammadiyah
}

\author{
Muhammad Habibi Miftakhul Marwa \\ Ilmu Hukum,Universitas Ahmad Dahlan Yogyakarta \\ Email. habibi.marwa@law.uad.ac.id
}

\begin{abstract}
Studies on the age limit of marriage are reviewed from various perspectives continue to be carried out by academics, because the age of marriage of a person is inherently part of achieving the goal of marriage, namely the realization of a happy and eternal family based on the One True God. The purpose of the study was to analyze the age limit setting of marriage perspective of muhammadiyah sakinah family. This research includes normative research using secondary legal materials obtained from library studies. The data obtained is analyzed qualitatively-descriptively using conceptual approach and statute approach. The results of this study show that the age of marriage perspective of positive law, and Islamic law has different arrangements, but has similarities in achieving the goal of marriage. The sakinah family was formed through a legitimate marriage. In the perspective of muhammadiyah sakinah family, choosing a partner should consider autonomy and adulthood. Maturity in the readiness of marriage is not just paying attention to puberty (biological maturity), but must be at the consideration of rusyd (psychological-social maturity) which if translated in into age is the age of 19 years as the Marriage Act.
\end{abstract}

Keywords: Marriage Age Limit; Sakinah's family; Muhammadiyah

\begin{abstract}
Abstrak
Kajian mengenai batas usia perkawinan ditinjau dari berbagai perspektif terus dilakukan oleh para akademisi, karena usia kawin seseorang bagian inheren untuk mencapai tujuan perkawinan, yaitu terwujudnya keluarga yang bahagia dan kekal berdasarkan Ketuhanan Yang Maha Esa. Tujuan penelitian ini untuk menganalisis pengaturan batas usia perkwinan perspektif keluarga sakinah Muhammadiyah. Penelitian ini termasuk penelitian normatif dengan menggunakan bahan hukum sekunder yang diperoleh dari studi pustaka. Data yang diperoleh dianalisis secara kualitatif-deskriptif dengan menggunakan pendekatan konsep (Conceptual Approach) dan pendekatan perundang-undangan (Statute Approach). Hasil penelitian ini menunjukkan bahwa usia perkawinan perspektif hukum positif, dan hukum Islam memiliki pengaturan berbeda, namun mempunyai kesamaan dalam meraih tujuan perkawinan. Keluarga sakinah dibentuk melalui perkawinan yang sah. Dalam perspektif keluarga sakinah Muhammadiyah, memilih pasangan harus mempertimbangkan otonomi dan usia dewasa. Kedewasaan pada kesiapan menikah bukan sekedar memperhatikan baligh (kedewasaan biologis), tetapi harus pada pertimbangan rusyd (kedewasaan psikologis-sosial) yang jika diterjemahkan dalam ke dalam usia adalah usia 19 tahun sebagaimana Undang-Undang Perkawinan.
\end{abstract}

Kata Kunci : Batas Usia Perkawinan; Keluarga Sakinah; Muhammadiyah 


\section{PENDAHULUAN}

Perbincangan mengenai batas usia minimal seseorang dapat melangsungkan perkawinan selalu menjadi perdebatan hangat di tengah masyarakat. Sebelum tahun 1974, penduduk Indonesia tunduk pada berbagai peraturan pernakwinan yang diwarisi dari berbagai negara kolonial. Pemerintah kolonial tidak pernah berusaha membawa warga negara di bawah satu Undang-Undang, namun hanya ikut andil dalam masalah keluarga jika ini diperlukan oleh tekanan eksternal. Sebagai contoh, dari Gereja di Belanda yang menginginkan peraturan khusus untuk sesama orang Kristen di Hindia (Judiasih and Dkk, 2018). Namun, pada 31 Juli 1973, Presiden Republik Indonesia menyampaikan RUU Perkawinan kepada DPR yang kemudian disahkan menjadi Undang-Undang Nomor 1 Tahun 1974 tentang Perkawinan. Undang-Undang Perkawinan tersebut salah satunya mengatur ketentuan batas minisal usia seseorang dapat melangsungkan perkawinan.

Pengaturan usia perkawinan yang telah ditetapkan relevan untuk kondisi masyarakat saat itu. Namun, seiring perkembangan sosial-kemasyarakat yang begitu cepat menyebabkan pengaturan usia kawin yang ada harus dilakukan penyesuaian. Akhirnya, tahun 2019 pemerintah menetapkan Undang- Undang Nomor 16 Tahun 2019 tentang Perubahan atas Undang-Undang Nomor 1 Tahun 1974 tentang Perkawinan, karena batas usia minimal perkawinan sebagaimana tertuang dalam Undang-Undang Nomor 1 Tahun 1974 tentang Perkawinan dipandang bertolak belakang dengan Undang-Undang Nomor 23 Tahun 2002 tentang Perlindungan Anak yang telah dirubah menjadi Undang-Undang Nomor 35 Tahun 2014 tentang Perubahan Atas Undang-Undang Nomor 23 Tahun 2002 tentang Perlindungan Anak. Undang-Undang Perkawinan terbaru menyatakan bahwa perkawinan laki-laki dan perempuan hanya diizinkan jika sudah mencapai usia 19 tahun, yang sebelumnya batas minimal bagi laki-laki 19 tahun dan perempuan 16 tahun. Adanya perubahan batas usia minimal khususnya perempuan dari 16 tahun menjadi 19 tahun adalah telah mengakomodir prinsip kesetaraan dan juga bentuk afirmasi yang progresif meskipun masih menyisakan persoalan khususnya tentang dispensasi nikah bagi yang belum mencapai usia minimal perkawinan.

Menurut Undang-Undang Perlindungan Anak, bagi calon pengantin yang belum mencapai usia 18 tahun, maka digolongkan perkawinan dini atau perkawinan di bawah umur atau perkawinan anak. Anak sebagai investasi masa depan bangsa, maka hak-hak dasarnya harus dilindungi. Berdasarkan data Kementerian Pemberdayaan Perempuan dan Perlindungan 
Anak (2019), dinyatakan 30,1\% atau sekitar 79,5 juta penduduk Indonesia adalah anak. Perkawinan di bawah umur akan berdampak terhadap pendidikan (putus sekolah), kesehatan (ibu dan anak), ekonomi (pekerja anak dan upah rendah), Kekerasan Dalam Rumah Tangga (KDRT), pola asuh anak yang salah, dan sebagainya. Menurut Survei Sosial Ekonomi Nasional (2018), perempuan yang menikah sebelum 18 tahun empat kali lebih kecil dalam menyelesaikan pendidikan Sekolah Menenegah Atas ke atas dibandingkan yang menikah 18 tahun atau lebih. Bahkan, ada sekitar 44,9\% perempuan yang menikah sebelum usia 18 tahun paling banyak hanya menyelesaikan pendidikan Sekolah Menengah Pertama. Dari aspek kesehatan, perempuan yang menikah dini empat kali peluang terjadi kehamilan risiko tinggi, dua kali risiko kematian saat melahirkan, dua kali berpeluang preklamsia, kontraksi rahim tidak oprtimal, risiko lahir premature, dan lainnya. Sedangkan, dampak ekonomi yang akan diderita bagi perempuan yang menikah sebelum usia 18 tahun hampir dua kali lebih banyak bekerja di sektor pertanian dibanding yang menikah usia di atas 18 tahun.

Muhammadiyah sebagai salah satu organisasi yang bergerak di bidang sosialkeagamaan memiliki cita-cita membangun keluarga sakinah sebagai perwujudan "Menegakkan dan menjunjung tinggi agama Islam sehingga terwujud masyarakat Islam yang sebenarbenarnya". Keluarga sakinah dalam pandangannya dijadikan gerbang pertama untuk melahirkan generasi baru yang lebih baik untuk masa depan suatu bangsa. Berdasarkan penjelasan di atas, melalui tulisan ini penulis akan membahas, bagaimana pengaturan batas usia perkawinan perspektif keluarga sakinah Muhammadiyah?

\section{METODE PENELITIAN}

Penelitian ini termasuk jenis penelitian hukum normatif, karena menggunakan data sekunder yang diperoleh dari hasil telaah kepustakaan atau studi pustaka yang berkaitan dengan masalah penelitian. Data sekunder terdiri bahan hukum primer berupa Undang-Undang Nomor 1 Tahun 1974 tentang Perkawinan dan Undang-Undang Nomor 16 Tahun 2019 tentang Perubahan Atas Undang-Undang Nomor 1 Tahun 1974 tentang Perkawinan, sedangkan bahan hukum sekunder berupa buku "Tuntunan Menuju Keluarga Sakinah" dan jurnal mengenai batas usia perkawinan dan keluarga sakinah. Data yang terkumpul kemudian dianalisis secara deskriptif-kualitatif dengan pendekatan perundang-undangan (Statute Approach) dan pendekatan konsep (Conceptual Approach) (Dewata and Achmad, 2010).

\section{PEMBAHASAN}

\section{Pengaturan Batas Usia Perkawinan Perspektif Hukum}


Menurut Roscoe Pound, hukum dapat difungsikan sebagai alat untuk melakukan rekayasa sosial (Djasmani, 2011). Tulisan ini hanya akan menjelaskan pengaturan batas minimal usia perkawinan menurut hukum positif (Undang-Undang Nomor 1 Tahun 1974 tentang Perkawinan dan Undang-Undang Nomor 16 Tahun 2019) dan hukum Islam. UndangUndang Nomor 1 Tahun 1974 tentang Perkawinan telah mengatur batas usia perkawinan yaitu apabila calon suami istri belum mencapai umur 21 tahun untuk bisa melangsungkan perkawinan maka harus mendapatkan izin kedua orang tuanya. Perkawinan hanya diizinkan jika pria sudah mencapai umur 19 tahun dan pihak wanita sudah mencapai 16 tahun. Meskipun Undang-Undang Perkawinan memperbolehkan menikah bagi perempuan yang berusia 16 tahun, tetapi usia segitu dipandang masuk kategori anak-anak yang secara fisik dan mental masih rentan dan belum matang dalam menghadapi konsekuensi perkawinan (Fawzi, 2014). Namun, sejak berlakunya Undang-Undang Nomor 16 Tahun 2019 tentang Perubahan atas Undang-Undang Nomor 1 Tahun 1974 Tentang Perkawinan, sebagaimana Pasal 7 ayat (1) bahwa pria dan wanita yang akan melangsungkan perkawinan harus sudah berusia 19 tahun. Berdasarkan penjelasan tersebut, terdapat dua lapis pembatasan usia minimal perkawinan. Kedua calon pasangan pengantin harus dipastikan sudah berusia 21 tahun. Apabila belum mencapai usia 21 tahun, maka harus memperoleh izin orang tuanya. Dapat izin orang tua tidak cukup, laki-laki dan perempuan yang akan melakukan perkawinan harus sudah berusia minimal 19 tahun. Adanya keharusan meminta izin kepada orang tua termasuk nilai-nilai positif yang harus dipertahankan dalam melangsungkan perkawinan.

Pasal 7 ayat (2) Undang-Undang Perkawinan menjelaskan manakala terjadi penyimpangan terhadap batas usia perkawinan yaitu menikah di bawah umur 19 tahun dapat dimintakan permohonan dispensasi kepada pengadilan atau pejabat lain yang diajukan oleh kedua orang tua pihak pria maupun wanita dengan tetap mempertimbangkan kehati-hatian dan alasan mendesak yang disertai bukti-bukti yang cukup. Pengaturan dispensasi nikah ini dapat dimaknai sebagai kebijakan hukum guna menganulir penyimpangan yang terjadi di masyarakat untuk memperoleh jalan keluar (solusi) apabila terdapat anak yang belum mencapai batas minimum usia kawin akan melangsungkan perkawinan (Tofif, 2014). Artinya, Pasal 7 ayat (2) ini masih membuka tafsir adanya peluang perkawinan yang belum mencapai usia 19 tahun dengan cara mengajukan permohonan dispensasi nikah.

Mengutip pendapat Andi Syamsu Alam, bahwa perpaduan antara Pasal 7 ayat (1) dan Pasal 6 ayat (2) karena adanya dispensasi kawin memberi kesan kepada publik bahwa telah hilang ketegasan hukum terhadap perkawinan di bawah umur sebagaimana ditetapkan Undang- 
Undang Perkawinan. Oleh karenanya, diperlukan sanksi tegas terhadap calon pengantin yang belum mencapai usia minimal perkawinan seperti diatur dalam undang-undang ini tanpa dispensasi pengadilan dan tidak sekedar denda (Candra, 2018).

Menurut Maman dan Satrio (dalam Musfiroh, 2016), pembatasan usia anak tersebut merupakan cara negara untuk melindungi warganya yang belum mampu mengemukakan pendapat dengan baik dan benar serta belum menyadari konsekuensi atas perbuatannya. Secara politik hukum, kebijakan ini untuk memastikan laju pembangunan sumber daya manusia berjalan sesuai yang diharapkan baik secara kualitas maupun kuantitas demi memenuhi kebutuhan di masa mendatang (Suhaili, 2018)

Pembahasan kedewasaan dalam khasanah hukum Islam mengalami perkembangan yang dinamis. Terjadi perbedaan pendapat di kalangan para ulama dalam menentukan konsep kedewasaan. Pertama, menentukan kedewasaan seseorang dengan mengidentifikasi tandatanda biologis yaitu minimal telah mimpi basah bagi laki-laki dan menstruasi pada perempuan. Jika seseorang telah mengalami tanda-tanda tersebut, maka sudah dianggap baligh. Kedua, menentukan kedewasaan dengan menggunakan kriteria umur (Yusuf, 2020).

Jika menggunakan kriteris umur, setidaknya sejak periode klasik (610-650) telah terjadi perbedaan pandangan pembatasan usia minimal perkawinan. Imam Hanafi berpendapat batas minimal usia seseorang diperbolehkan menikah adalah laki-laki sudah mengalami mimpi basah dengan perkiraan usia 12-18 tahun, sedangkan perempuan dimulai ketika mengalami menstruasi antara usia 9-17 tahun. Pandangan lain disampaikana oleh Imam Malik yang menyatakan batas minimal perkawinan laki-laki dan perempuan adalah 17 tahun. Imam Hanbali dan Imam Syafi'I berpendapat batas minimal usia dapat dilangsungkannya perkawinan yakni 15 tahun. Pandangan para imam madzhab ini bertahan hingga periode pertengahan (1250-1800). Hal ini dapat dimengerti mengingat saat itu terdapat anggapan pintu ijtihad telah tertutup, sehingga para ulama tidak memiliki keberanian dan kemerdekaan untuk mencurahkan tenaga dan fikiran untuk melakukan penemuan hukum yang sesuai dengan kondisi sosial kemasyarakatan (Latief, 2016). Pada periode modern (1800), ulama-ulama pengikut imam madzhab mulai mengembangkan batas minimal usia perkawinan, seperti ulama Syafi'iyah menetapkan 15 tahun, ulama Hanafiyah 17 tahun, ulama Malikiyah 18 tahun (Rohman, 2016). Yusuf Musa memberikan batas minimal perkawinan berusia 21 tahun, sedangkan March Hendry Frank memberikan pembatasan lebih ketat bahwa kematangan seseorang untuk dapat melangsungkan perkawinan adalah laki-laki berusia 25 tahun dan perempuan 20 tahun (Latief, 2016). 
Ketentuan batas usia perkawinan sebagaimana dalam Pasal 7 ayat (1) UU Perkawinan maupun Pasal 15 Kompilasi Hukum Islam (KHI) didasarkan pada pertimbangan kemaslahatan keluarga dan rumah tangga perkawinan, yaitu minimal calon suami berumur 19 tahun dan calon istri 16 tahun (sekarang keduanya harus berusia minimal 19 tahun). Apabila calon pengantin belum mencapai 21 tahun, maka harus mendapatkan izin kedua orang tua atau wali atau pengadilan. Berbagai pengaturan tersebut menghendaki supaya calon suami-istri harus sudah matang secara jiwa dan raga sebelum melaksanakan perkawinan supaya tujuan perkawinan dapat terwujud dan tidak berakhir dengan perceraian. Dengan demikian, sebisa mungkin perkawinan di bawah umur ditolak untuk mengurangi terjadinya perceraian akibat pasangan suami-istri kurang mampu menjalankan hak dan kewajibannya secara proporsional.

Pengaturan batas usia perkawinan ini dalam rangka untuk memastikan bahwa para calon pengantin harus sudah matang secara emosional, psikologi, ekonomi, dan sosial, karena hal tersebut merupakan aspek terpenting untuk menjaga dan memastikan kelangsungan perkawinan. Sehingga, kesehatan suami isteri dan keturunan yang akan ada tetap terjaga dengan baik, menjamin terpenuhinya kebutuhan dasar setiap keluarga, serta memberikan penegasan sekaligus menghilangkan kekaburan terhadap berbagai macam bentuk penafsiran mengenai batas usia perkawinan.

\section{Keluarga Sakinah Muhammadiyah}

Konsep keluarga sakinah Muhammadiyah secara resmi disahkan berdasarkan Surat Keputusan Pimpinan Pusat Muhammadiyah Nomor 101/KEP/1.1/B/2015 tentang Tanfidz Keputusan Musyawarah Nasional Tarjih XXVIII dan hasil musyawarah tersebut dibukukan dengan judul "Tuntunan Menuju Keluarga Sakinah". Keluarga sakinah berasal dari dua kata "keluarga" dan "sakinah". Undang-Undang Nomor 52 Tahun 2009 tentang Perkembangan Kependudukan dan Pembangunan Keluarga menjelaskan keluarga adalah unit terkecil dalam masyarakat yang terdiri dari suami-istri, atau suami, istri, dan anaknya, atau ayah dan anaknya, atau ibu dan anaknya. Keluarga dalam terminologi Al-Qur'an menggunakan istilah al-ahl sebagaimana merujuk surat At-Tahrim (66) : 6 .

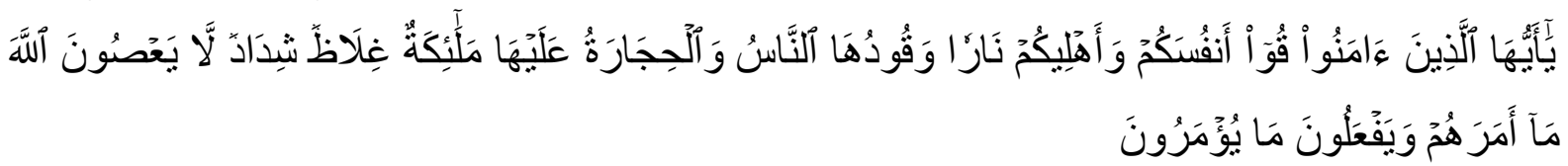

Artinya : " Hai orang-orang yang beriman, peliharalah dirimu dan keluargamu dari api neraka yang bahan bakarnya adalah manusia dan batu; penjaganya malaikat-malaikat yang kasar, keras, dan tidak mendurhakai Allah terhadap apa yang diperintahkan-Nya kepada mereka dan selalu mengerjakan apa yang diperintahkan.” 
Al-Maraghi dalam tafsirnya menjelaskan jika al-ahl yaitu keluarga yang terdiri ayah, ibu, anak, dan pembantu yang kemudian disebut keluarga kecil. Sedangkan, keluarga dalam arti luas terdiri dari anggota keluarga kecil ditambah kerabat dekat maupun jauh. Keluarga sakinah menganut konsep keluarga kecil dan keluarga luas, di mana memiliki tanggung jawab untuk mewujudkan kesejahteraan dalam segala aspek kehidupan keluarga inti dan kerabat dari garis suami-istri ('Aisyiyah and Muhammadiyah, 2017).

Sedangkan, sakinah diserap dari bahasa Arab sakana-yaskunu-suknan, yang berarti ketenangan dan kemuliaan. Artinya, ketika pasangan suami-istri telah berumah tangga, maka rumah tersebut disebut sakan (damai) karena dari tempat itulah mereka diharapkan akan memperoleh ketenangan batin dan batin (Prasetiawati, 2017). Di antara ayat Al-Qur'an yang menjelaskan tentang ketenangan (sakinah) adalah surat Al-Fath (48) : 4.

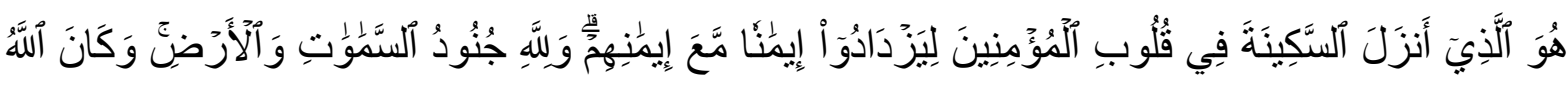
عَلِيمًا حَكِيمّا

Artinya: "Dialah yang telah menurunkan ketenangan ke dalam hati orang-orang mukmin supaya keimanan mereka bertambah di samping keimanan mereka (yang telah ada). Dan kepunyaan Allah-lah tentara langit dan bumi dan adalah Allah Maha Mengetahui lagi Maha Bijaksana”.

Konsep keluarga sakinah ini merupakan penjabaran dari firman Allah dalam surat ArRum (30) : 21.

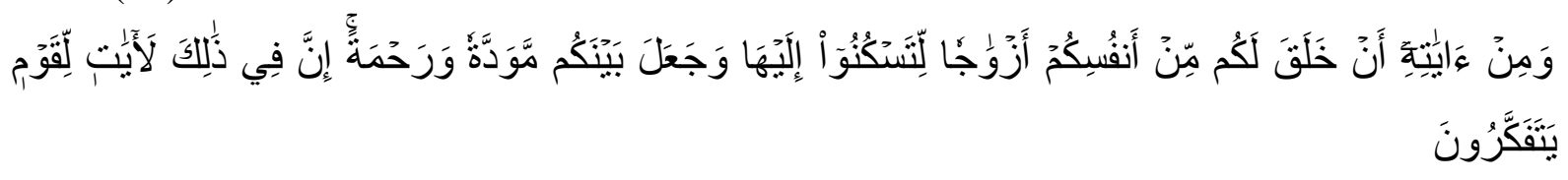

Artinya : "Dan di antara tanda-tanda (kebesaran)-Nya ialah Dia menciptakan pasangan-pasangan untukmu dari jenismu sendiri, agar kamu cenderung dan merasa tenteram kepadanya, dan Dia menjadikan di antaramu rasa kasih dan sayang. Sungguh, pada yang demikian itu benar-benar terdapat tanda-tanda (kebesaran Allah) bagi kaum yang berpikir."

Berdasarkan ayat di atas tujuan rumah tangga adalah untuk mewujudkan sakinah (ketentraman atau ketenangan) dengan dasar mawaddah wa rahmah (saling mencintai dan penuh kasih sayang). Mawaddah merupakan kasih sayang yang lahir dari interaksi fisik, sedangkan rahmah adalah kasih sayang yang lahir dari interaksi batin. Jika mawaddah adalah 
cinta potensial, maka rahmah adalah cinta aktual. Mawaddah wa rahmah merupakan media perekat antara anggota keluarga yang menjadi sumber suasana ketentraman, kedamaian, keharmonisan, keadilan, kejujuran, dan keterbukaan dalam rumah tangga. Sehingga, terwujudnya kesakinahan berkeluarga merupakan hasil dari berkembangnya mawaddah wa rahmah. Pembentukan keluarga sakinah dengan tujuan untuk membentuk insan yang bertaqwa dan masyarakat yang berkemajuan dibangun atas lima asas, yaitu karamah insaniyah, pola hubungan kesetaraan, keadilan, mawaddah wa rahmah, dan pemenuhan hidup sejahtera dunia dan akhirat. Keluarga sakinah memiliki fungsi sangat strategis yang tidak dapat tergantikan oleh institusi lain, yaitu fungsi keagamaan, reproduksi, peradaban, kasih sayang, perlindungan, kemasyarakatan, pendidikan, ekonomi, lingkungan, internalisasi nilai-nilai keislaman yang berkemajuan, dan fungsi kaderisasi ('Aisyiyah and Muhammadiyah, 2017). Keluarga sakinah sebagaimana yang dikonsepkan dalam Al-Qur'an dibangun berdasarkan pondasi agama kuat, melalui perkawinan suci yang sah dengan landasan cinta, mawaddah, rahmah dan amanah, di mana masing-masing anggota keluarga memiliki kemampuan untuk bertanggungjawab mewujudkan kedamaian dengan pembagian tugas secara proporsional sesuai peran, status dan fungsinya.

\section{Pengaturan Batas Usia Perkawinan Sebagai Upaya Mewujudkan Keluarga Sakinah}

Pasal 1 Undang-Undang Nomor 1 Tahun 1974 tentang Perkawinan, mengaitkan perkawinan dengan aspek agama dan keyakinan, yaitu "Perkawinan merupakan ikatan lahir batin antara seorang pria dengan seorang wanita sebagai suami-istri dengan tujuan membentuk keluarga (rumah tangga) yang bahagia dan kekal berdasarkan Ketuhanan Yang Maha Esa.”

Usia perkawinan memiliki konsekuensi logis dari tujuan perkawinan yaitu calon suami atau istri dituntut memiliki kematangan jasmani dan rohani ketika memasuki jenjang perkawinan. Maksudnya, usia perkawinan menjadi bagian yang tidak terpisahkan dengan tujuan perkawinan dan menjiwai dasar perkawinan. Tujuan perkawinan di antaranya untuk memperoleh kebahagiaan yang sifatnya kekal dan abadi. Rumusan tersebut memiliki kesamaan tujuan dengan perkawinan (pernikahan) Pasal 3 Kompilasi Hukum Islam (KHI), yakni membentuk keluarga sakinah (tenang, tenteram, dan bahagia), yang dibina dengan cinta dan kasih sayang (mawaddah, dan rahmah) oleh kedua belah pasangan. Suami istri wajib saling menghormati, setia, dan memberi bantuan secara lahir dan batin supaya dapat membangun bahtera keluarga penuh kebahagiaan untuk selama-lamanya. Oleh karena itu, untuk mewujudkan perkawinan yang membahagiakan dibutuhkan cara yang dapat mengarahkan menuju kesakinahan keluarga. 
Adanya pengaturan usia perkawinan sebagai salah satu upaya untuk merekayasa terwujudnya keluarga yang bahagia dan kekal. Memahami aturan batas usia kawin menjadi bagian penting dari persiapan fisik dan mental untuk melaksanakan pernikahan yang merupakan prosesi sakral bagi manusia. Mempertimbangkan faktor usia perkawinan menjadi hal penting dalam memilih pasangan hidup, mengingat dalam sebuah perkawinan ada tanggung jawab yang harus dipikul oleh suami-istri maupun orang tua dari anak-anak yang akan ada.

Umur memiliki keterkaitan dengan beberapa faktor dalam perkawinan. Adanya pengaturan batas umur perkawinan sebagaimana yang tercantum dalam Undang-Undang Perkawinan apabila ditelusuri secara mendalam, maka faktor fisiologis atau kesehatan menjadi pertimbangan utama. Hal ini ditegaskan dalam penjelasan Pasal 7 ayat 1 Undang-Undang Nomor 1 Tahun 1974 tentang Perkawinan yang menyatakan: "Untuk menjaga keselamatan suami istri dan keturunan, perlu ditetapkan batas- batas umur perkawinan." Perempuan yang belum cukup umur dapat menyebabkan kehamilan berisiko. Perempuan berusia 15-19 tahun potensi meninggal saat melahirkan lebih besar dibandingkan mereka yang berusia 20-25 tahun. Perempuan di bawah umur yang sedang hamil rentan pendarahan, keguguran, terserang kanker serviks, persalinan sulit, bahkan dapat menyebabkan ibu meninggal dunia (Koalisi Perempuan Indonesia Untuk Keadilan dan Demokrasi, 2019). Secara psikologis perkawinan di bawah umur dipandang belum memiliki kesiapan untuk mengambil peran dan tanggung jawab sebagai suami-istri maupun orang tua bagi anaknya. Ketidaksiapan tersebut akhirnya menjadi awal terjadinya perselisihan rumah tangga, hingga akhirnya banyak terjadi perceraian (Yusuf, 2020).

Kesiapan secara ekonomi dan sosial berperan sekali untuk menentukan keutuhan kehidupan rumah tangga seseorang. Semakin dewasa usia seseorang lebih mungkin memiliki kesiapan dan kematangan dalam mengupayakan segala kebutuhan yang dijadikan sebagai modal untuk membangun bahtera keluarga. Sebaliknya, semakin melangsungkan perkawinan di usia muda mungkin dapat diperkirakan akan mengalami kesulitan ekonomi dan interaksi sosial yang justru dikhawatirkan dapat mengganggu keberlangsungan rumah tangga. Akibatnya apa yang menjadi tujuan luhur perkawinan yaitu memperoleh kebahagiaan yang kekal sulit terwujud. Maka dapat dibenarkan jika suatu negara membuat pengaturan batas usia calon pasangan pengantin sebagaimana yang tertuang dalam Undang- Undang Nomor 1 Tahun 1974 tentang Perkawinan menjadikan maksud dan tujuan perkawinan dapat terwujud (Suhaili, 2018). Berbagai pengaturan tersebut dibuat dalam rangka menjamin keabsahan dan kebahagiaan yang kekal dari suatu perkawinan. Mengingat pengaturan usia kawin berkaitan erat terhadap akibat-akibat hukum yang lahir dari perbuatan hukum berupa perkawinan yang 
kemudian akan menimbulkan hak dan kewajiban bagi pasangan suami-istri baik menyangkut status perkawinan, anak (keturunan) yang akan ada, maupun harta.

Pengaturan usia perkawinan dalam perspektif keluarga sakinah Muhammadiyah sebagai usaha mewujudkan keluarga sakinah itu sendiri. Karena perkawinan bukan saja untuk memuaskan kebutuhan biologis semata, maka dibutuhkan kesiapan psiko-sosial dan kemampuan mengelola konflik- konflik yang akan terjadi sehingga rumah tangga keluarga tetap bertahan selamanya ('Aisyiyah and Muhammadiyah, 2017). Membangun keluarga sakinah tidak hanya disandarkan pada fungsi organ reproduksi, melainkan harus dipertimbangkan atas kedewasaan (rusyd) seseorang di antaranya dengan melihat usia perkawinan. Al-Qur'an telah memberikan petunjuk betapa pentingnya kematangan usia perkawinan seseorang, karena perkawinan itu sendiri akan banyak melahirkan tanggung jawab bagi pasangan suami-istri. Oleh karena itu, dibutuhkan kedewasaan secara biologis, psikologis, sosial, dan ekonomi demi terwujudnya keluarga sakinag. Hal ini ditegaskan dalam firman Allah surat An-Nisa' (4) : 6.

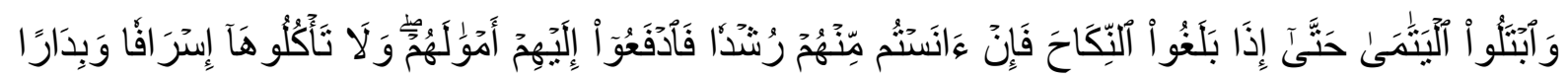

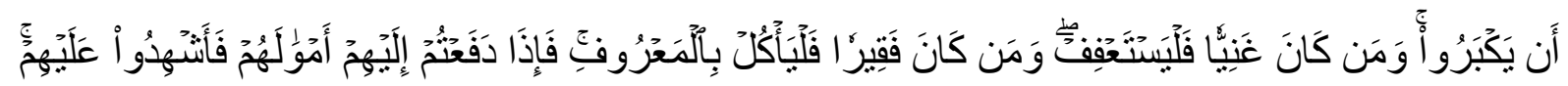
وَكَفَى بِالَلَّهِ حَسِيبًا

Artinya : "Dan ujilah anak yatim itu sampai mereka cukup umur untuk kawin. Kemudian jika menurut pendapatmu mereka telah cerdas (pandai memelihara harta), maka serahkanlah kepada mereka harta-hartanya. Dan janganlah kamu makan harta anak yatim lebih dari batas kepatutan dan (janganlah kamu) tergesa-gesa (membelanjakannya) sebelum mereka dewasa. Barang siapa (di antara pemelihara itu) mampu, maka hendaklah ia menahan diri (dari memakan harta anak yatim itu) dan barangsiapa yang miskin, maka bolehlah ia makan harta itu menurut yang patut. Kemudian apabila kamu menyerahkan harta kepada mereka, maka hendaklah kamu adakan saksi-saksi (tentang penyerahan itu) bagi mereka. Dan cukuplah Allah sebagai Pengawas (atas persaksian itu).”

Menurut Muhammadiyah ayat di atas menjelaskan tanda-tanda kedewasaan yang harus menjadi pertimbangan bagi yang akan menikah, yaitu telah mencapai usia mampu menikah yang ditandai dengan mulai berfungsinya organ seksual laki-laki mimpi basah sedangkan perempuan sudah haid, dan telah mencapai rusyd yakni dewasa secara biologis, psikologis, ekonomi, sosial, dan intelektual. Muhammadiyah berpandangan usia dewasa seseorang 
sehingga layak melangsungkan perkawinan tidak hanya didasarkan pada aspek baligh, tetapi harus sudah mencapai rusyd yang jika dikonversi dalam angka adalah berumur 18 tahun (Muhammadiyah, 2018). Hal ini dapat dimengerti bahwa ukuran baligh seseorang belum tentu mencapai rusyd, sedangkan jika telah rusyd maka orang tersebut sudah baligh. Dalam pengertian lain dewasanya seseorang berdasarkan fisik belum tentu menunjukkan kedewasaan secara psikologi, sosial, dan ekonomi. Intinya batas minimal usia kawin bagi calon pengantin yang dipedomani Muhammadiyah adalah mengutamakan kriteria rusyd dibandingkan baligh.

Patokan umur 18 tahun ini mengikuti rumusan anak dalam Undang-Undang Pelindungan Anak. Anak menurut pandangan Muhammadiyah adalah mereka yang belum berusia 18 tahun dalam urusan muamalah dan 12 tahun untuk urusan ibadah. Sedangkan, usia perkawinan menurut konsep keluarga sakinah Muhammadiyah mendasarkan pada kebijakan pemerintah yang dituangkan dalam Undang-Undang Nomor 1 Tahun 1974 tentang Perkawinan yang menetapkan batas usia minimal perkawinan yaitu usia 19 tahun bagi laki-laki dan 16 tahun untuk perempuan ('Aisyiyah and Muhammadiyah, 2017). Namun, mengingat UndangUndang Nomor 16 Tahun 2019 tentang Perkawinan telah merubah aturan batas minimal usia perkawinan di mana laki-laki dan perempuan yang akan menikah minimal harus berusia 19 tahun, maka sekarang Muhammadiyah berpijak pada aturan terbaru tersebut.

Adanya pengaturan usia perkawinan karena perkawinan akan mempengaruhi banyak hal terhadap diri seseorang, rumah tangga atau keluarga yang akan dibina. Dalam keluarga sakinah diharuskan dipenuhinya kebutuhan hidup supaya potensi diri yang dimiliki dapat dikembangkan secara normal dan optimal. Kebutuhan tersebut meliputi kebutuhan spiritual, pendidikan, ekonomi, sosial, kesehatan, dan lingkungan. Pasangan yang belum mencapai usia dewasa dipandang akan kesulitan dalam pemenuhan kebutuhan dasar tersebut ('Aisyiyah and Muhammadiyah, 2017).

Orang tua berkewajiban melakukan berbagai pendekatan dan konseling agar anakanaknya tidak keliru dalam memilih pasangan, diutamakan dengan mempertimbangkan aspek agama di samping pendidikan, sosial, dan ekonomi (Zaini, 2015). Untuk mengikuti sunnah Rasul, apabila sudah tiba waktunya menikah maka orang tua harus segera menikahkan anaknya dan dicatatkan di hadapan pegawai pencatat nikah.

Berdasarkan penjelasan di atas, maka dapat dipahami bahwa Islam telah memberikan pedoman tentang kedewasaan dan usia perkawinan yang hendaknya dipenuhi oleh pasangan yang akan melakukan pernikahan. Pasangan yang belum memenuhi usia perkawinan rawan 
terjadi perselisihan yang menjadikan perkawinan tidak berusia lama. Meskipun perkawinan tersebut akan tetap dipertahankan, tetapi rumah tangganya dipenuhi dengan ketidaktenangan.

\section{SIMPULAN}

Undang-Undang Nomor 16 Tahun 2019 tentang Perubahan Atas Undang-Undang Nomor 1 Tahun 1974 tentang Perkawinan sebagai hukum posistif di Indonesia menegaskan batas minimal usia laki-laki dan perempuan diizinkan melakukan perkawinan jika sudah mencapai 19 tahun, meskipun penyimpangan terhadap ketentuan usia kawin tersebut dapat dimintakan permohonan dispensasi kawin kepada pengadilan dengan pertimbangan mendesak dan bukti yang sah dan menguatkan. Pengaturan usia pernikahan dalam hukum Islam sebagian ulama mendasarkan pada tanda-tanda fisiologis haid pada perempuan dan mimpi basah bagi laki-laki, sebagian lainnya berpijak pada ketentuan umur. Adanya pengaturan usia perkawinan dalam rangka untuk menjaga kesehatan pasangan suami-istri dan keturunan yang akan ada, memberikan perlindungan terhadap anak, dan mewujudkan keluarga sakinah. Batas usia perkawinan menurut pandangan keluarga sakinah Muhammadiyah selain menggunakan kriteria tanda-tanda fisik (Baligh) juga mengutamakan pertimbangkan aspek kedewasaan (Rusyd) secara psikologi, sosial, dan ekonomi jika dikonversi dalam bentuk angka berusia sekitar 18 atau 19 tahun sebagaimana ketentuan batas minimal usia perkawinan yang ditetapkan Undang-Undang Perkawinan. Pentingnya mempertimbangkan usia perkawinan, karena perbuatan hukum perkawinan akan menimbulkan banyak tanggung jawab bagi pasangan suami istri dan orang tua bagi keturunan yang akan ada.

\section{DAFTAR PUSTAKA}

\section{Buku}

Aisyiyah, P. P. and Muhammadiyah, M. T. dan T. P. P. (2017) Tuntunan Menuju Keluarga Sakinah. II. Yogyakarta: Suara Muhammadiyah.

Candra, M. (2018) Aspek Hukum Perlindungan Anak di Indonesia: Analisis tentang Perkawinan di Bawah Umur. 1st edn. Jakarta: Prenadamedia Group.

Dewata, M. F. N. and Achmad, Y. (2010) Dualisme Penelitian Hukum Normatif \& Empiris. I. Jakarta: Pustaka Pelajar.

Judiasih, S. D. and Dkk (2018) Perkawinan Bawah Umur di Indonesia: Beserta Perbandingan Usia Perkawinan dan Praktik Perkawinan Bawah Umur di Beberapa Negara. Kesatu. Edited by D. Sumayyah. Bandung: PT. Refika Aditama.

Muhammadiyah, M. T. dan T. P. P. (2018) Materi Musyawarah Nasional Tarjih Muhammadiyah XXX. I. Yogyakarta: Panitia Muasyawarah Nasional Tarjih Muhammadiyah XXX.

\section{Jurnal}

Djasmani, H. Y. (2011) 'Hukum Sebagai Alat Rekayasa Sosial Dalam Praktek Berhukum Di 
Indonesia', Masalah Masalah Hukum, 40(3), pp. 365-374.

Fawzi, M. A. (2014) Batas Minimal Usia Perkawinan Menurut Undang-Undang Nomor 1 Tahun 1974 Tentang Perkawinan Dalam Perspektif Hukum Islam dan Kesehatan Reproduksi. Universitas Islam Negeri Sunan Kalijaga.

Koalisi Perempuan Indonesia Untuk Keadilan dan Demokrasi, D. (2019) Naskah Akademik RUU Perubahan UU No.1 Tahun 1974 Tentang Perkawinan.

Latief, M. N. H. (2016) 'Pembaharuan Hukum Keluarga Serta Dampaknya Terhadap Pembatasan Usia Minimal Kawin dan Peningkatan Status Wanita', Jurnal Hukum Novelty, 7(2), p. 196. doi: 10.26555/novelty.v7i2.a5467.

Musfiroh, M. R. (2016) 'Pernikahan Dini dan Upaya Perlindungan Anak di Indonesia', De Jure: Jurnal Hukum dan Syariah, 8(2), pp. 64-73. doi: 10.18860/j-fsh.v6i1.3192.3.

Prasetiawati, E. (2017) 'Penafsiran Ayat-Ayat Keluarga Sakinah, Mawaddah Wa Rahmah Dalam Tafsir Al-Hisbah Dan Ibnu Katsir', Comparative Tafseer, Sakinah Family, Mawaddah, Wa Rahmah, 05(1), pp. 1-29.

Rohman, H. (2016) 'Batas Usia Ideal Pernikahan Perspektif Maqasid Shariah', Journal of Islamic Studies and Humanities, 1(1), p. 67. doi: 10.21580/jish.11.1374.

Suhaili, A. (2018) 'Relevansi Batas Usia Perkawinan Dalam Membentuk Keluarga Sakinah', Al-Bayan, 1(1), pp. 1-15.

Tofif (2014) 'Kedewasaan Janda/Duda Pasca-Dispensasi Kawin', Varia Peradilan, (349).

Yusuf (2020) 'Dinamika Batasan Usia Perkawinan di Indonesia: Kajian Psikologi Dan Hukum Islam', JIL : Journal of Islamic Law, 1(2), pp. 200-217. doi: 10.24260/jil.v1i2.59.

Zaini, A. (2015) 'Membentuk Keluarga Sakinah Melalui Bimbingan Dan Konseling Pernikahan', Bimbingan Konseling Islam, 6(1), pp. 89-106. 